\begin{tabular}{l|c|c}
\hline \hline Vol. 200: 297-301, 2000 & $\begin{array}{c}\text { MARINE ECOLOGY PROGRESS SERIES } \\
\text { Mar Ecol Prog Ser }\end{array}$ & Published July 14 \\
\hline \hline
\end{tabular}

NOTE

\title{
Species diversity of the whale community in the Antarctic
}

\author{
Fujio Kasamatsu*
}

Marine Ecology Research Institute, 3-29, Jinbo-cho, Kanda, Chiyoda, Tokyo 101-0051, Japan

\begin{abstract}
The impact of commercial exploitation of whales on species diversity in the Antarctic whale community has not yet been documented. I report a correlation between the lowest species diversity and the largest biomass in the high productivity region near the ice-edge. Species diversity was higher and constant in waters beyond $60 \mathrm{n}$ miles $(\sim 111 \mathrm{~km})$ away from the ice-edge. Density and biomass showed the opposite trend. Species diversity increased with time in a part of the study area where large whales were depleted, but numbers are now recovering. This suggests that the whale community is moving toward a new balance of species composition during its recovery from past whaling impacts.
\end{abstract}

KEY WORDS: Cetacean - Distribution - Species diversity · Community $\cdot$ Antarctic $\cdot$ Sightings

More than 330000 blue whales Balaenoptera musculus were exploited in the Antarctic during the 1904 to 1978 period (Tonnessen \& Johnsen 1982). There can be little doubt that the extensive exploitation of large whales (blue whale, fin whale Balaenoptera physalus, humpback whale Megaptera novaeangliae and sperm whale Physeter macrocephalus) significantly affected the ecosystems of which they were an important part. The removal of many large whales affected species diversity as well as population dynamics, and perhaps the inter-specific relationships at virtually all trophic fauna levels (Laws 1985, Bengston \& Laws 1985). While much work on Antarctic marine mammals has been performed (e.g. Mackintosh 1965, Laws 1977. Brown \& Lockyer 1984, Kasamatsu \& Joyce 1995, Kasamatsu et al. 1996, 1998a,b, 2000a,b), species diversity before and after exploitation has never been documented. Information on the current whale species diversity is an important step in identifying changes in community structure due to recovery from exploitation as well as the influence of changes in the earth's cli-

„E-mail: kasamats@sepia.ocn.ne.jp mate system and its effect on the Southern Ocean ecosystem (Loeb et al. 1997, de la Mare 1997).

Materials and methods. Since 1978, annual data on distribution and density of cetaceans in Antarctic waters have been documented from systematic shipboard sightings. The International Whaling Commission/International Decade of Cetacean Research (IWC/ IDCR) Southern Hemisphere Minke Whale Assessment Cruises (IDCR cruises) started in 1978/79 with cooperation between the Scientific Committee of the IWC and the Japanese government (Best \& Butterworth 1980, Best \& Ohsumi 1980). All research vessels used in this program were converted whale catchers ( 750 to 900 gross tonnes) and thus were ideally suited for whale sightings surveys. The IDCR cruises were conducted in mid-summer (late December to early February; Kasamatsu et al. 1988). The research area was divided into 4 to 6 strata, and the surveys extended mainly from 58 to $60^{\circ} \mathrm{S}$ to the ice-edge (an area ranging from about 300 to $360 \mathrm{n}$ miles [ 556 to $\sim 667 \mathrm{~km}$ ] from the ice-edge; Kasamatsu et al. 1988). The vessels usually maintained a constant speed of 12 knots $\left(-22 \mathrm{~km} \mathrm{~h}^{-1}\right.$, and a continuous watch for whales was conducted from $04: 00$ to $20: 00 \mathrm{~h}$ each day, weather permitting. For all cetacean species encountered, the number of individuals, their position (latitude and longitude), and other relevant data were recorded. The ice-edge positions used in this paper were provided by direct observation of the ice-edge from the research vessels.

I used sighting data from 5 of the IDCR cruises in the Indian Ocean sector of the Antarctic (defined to be between $20^{\circ}$ and $120^{\circ}$ E longitude) because the largest data set from the cruises was recorded in this area. Additionally, the ice-edge configuration was primarily in an east-west direction, thus simplifying the analysis. The surveys in this region were conducted in $1978 / 79$ $\left(70^{\circ}-120^{\circ} \mathrm{E}\right), 1979 / 80\left(20^{\circ}-70^{\circ} \mathrm{E}\right), 1984 / 85\left(70^{\circ}-100^{\circ} \mathrm{E}\right)$, $1987 / 88\left(20^{\circ}-70^{\circ} \mathrm{E}\right)$, and $1988 / 89\left(70^{\circ}-120^{\circ} \mathrm{E}\right)$. The 


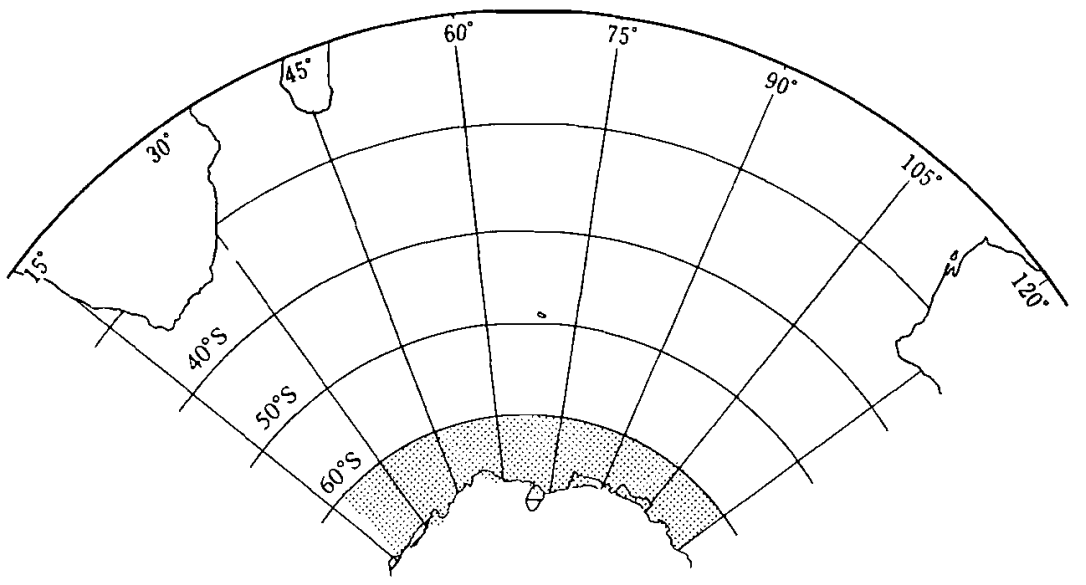

Fig. 1. Study area (shaded) in the Indian Ocean sector of the Atlantic school size of species $i$ in the $j$ th stratum, and $\widehat{g_{i}}(0)$ is the probability that whales are seen on the trackline of species $i . \hat{w}_{i}, \bar{s}_{i}$, and $\widehat{g_{j}}(0)$ were taken from Kasamatsu (1993) and Kasamatsu \& Joyce (1995) (Table 1). The coefficient of variation of $\widehat{D_{i j}}$ was calculated as follows:

$$
\begin{aligned}
\operatorname{CV}\left(\widehat{D_{i j}}\right)^{2}= & \operatorname{CV}\left(\widehat{n_{i j} / L_{j}}\right)^{2}+\operatorname{CV}\left(\bar{s}_{i j}\right)^{2} \\
& +\operatorname{CV}\left(\widehat{g_{i}}(0)\right)^{2}
\end{aligned}
$$

Species diversity was calculated using the index of species diversity $\left(H^{\prime}\right)$ based on information theory (Shannon \& Weaver 1963, Pielou 1966).

Five baleen whale species as well as 3 species and 2 families of odontocetes (toothed whales or dolphins) were identified as major residents in Antarctic waters and were considered in this paper. The whale species were the blue whale, fin whale, sei whale Balaenoptera borealis, minke whale research area and the cruise tracks with ice-edge for each cruise are shown in Figs. $1 \& 2$.

Estimates of density, biomass and species diversity were made in a latitudinal direction, since Antarctic waters are deep and surround a major land mass, connections to the Pacific, Atlantic, and Indian ocean basins are virtually continuous, and the fauna changes mainly in the latitudinal dimension (King 1964, Hunt \& Nettleship 1988, Kasamatsu et al. 1988, 1996). I also considered the relationship between the sea ice and the spatial structure of the whale community because the ice-edges and the marginal ice zone in the Antarctic are known as important habitats that significantly contribute to Antarctic productivity (Smith \& Nelson 1986, Ainley et al. 1986, 1988, Eicken 1992, Siegel \& Loeb 1995).

The density (number of whales or dolphins per $1000 \mathrm{n}$ miles $\left.^{2}\left[-3430 \mathrm{~km}^{2}\right]\right)$ for each cetacean species in $60 \mathrm{n}$ mile $(\sim 111 \mathrm{~km})$ band from the ice-edge was calculated using the line-transect method (Buckland et al. 1993). The following equation was used to estimate density:

$$
\widehat{D_{i j}}=\frac{n_{i j} \bar{s}_{i j}}{2 L_{j} \hat{w_{i}} \widehat{g_{i}(0)}}
$$

where $\widehat{D_{i j}}$ is the density of whales of species $i$ in the $j$ th stratum from the ice-edge, $n_{i j}$ is the number of schools seen during normal searching mode for species $i$ in the $j$ th stratum, $L_{j}$ is the search distance in the $j$ th stratum, $\hat{w}_{i}$ is the effective search half-width of species $i$ calculated from the Hazard rate model (Buckland et al. 1993), $\bar{s}_{i j}$ is the mean
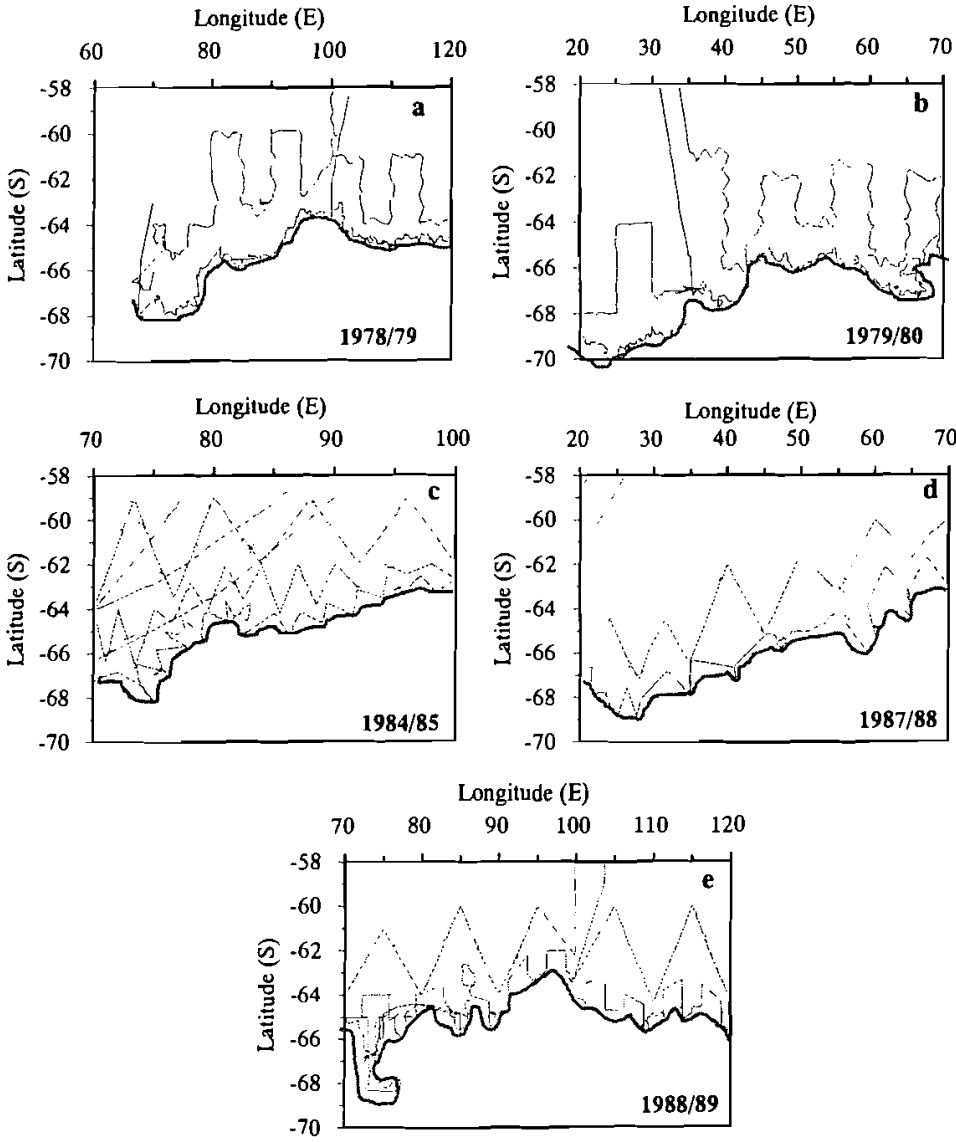

Fig. 2. Cruise tracks of the research vessels in the Indian Ocean sector of the Antarctic waters. (a) $1978 / 79\left(70^{\circ}-120^{\circ} \mathrm{E}\right)$, (b) $1979 / 80\left(20^{\circ}-70^{\circ} \mathrm{E}\right)$, (c) $1984 / 85\left(70^{\circ}-100^{\circ} \mathrm{E}\right)$, (d) $1987 / 88\left(20^{\circ}-70^{\circ} \mathrm{E}\right)$, and (e) $1988 / 89\left(70^{\circ}-120^{\circ} \mathrm{E}\right)$ 
B. acutorostrata and humpback whale. The odontocete species and families were the sperm whale, killer whale Orcinus orca, long-finned pilot whale Globicephala melaena, and beaked whale (family Ziphiidae, of which the majority were southern bottlenose whales $\mathrm{Hy}$ peroodon planifrons, with others being Arnoux's beaked whale Berardius arnuxii, strap-toothed whale Mesoplodon layardii, and gray's beaked whale Mesoplodon grayi). Ziphiids were pooled for the entire family Ziphiidae, rather than treating each species separately, because of the difficulties of species identification among family members due to their prolonged dives, wariness of vessels, limited distinguishing physical characteristics and their descriptions; however, most of the ziphiids (more than 90\%) were southern bottlenose whales (Kasamatsu et al. 1988). Two oceanic dolphins (family Delphinidae consisting of the hourglass dolphin Lagenorhynchus cruciger and the southern right-whale dolphin Lissodelphis peronii) were also treated as 1 group (dolphins); most of the dolphins were hourglass dolphins (Kasamatsu et al. 1988). The right whale Eubalaena glacialis and some coastal dolphins (e.g. Peale's dolphin Lagenorhynchus australis) also occur in the Antarctic waters (Kasamatsu 1993, Kasamatsu et al. 1988), but were not considered in the present analysis due to their rare occurrence in the study area.

Biomass was calculated as $\Sigma \widehat{D_{i j}} \times B_{i}$. Mean body weight $\left(B_{j}\right)$ for blue, fin, sei, humpback, minke, sperm, ziphiid, killer, and long-finned pilot whales, and dolphins were $79.5,45.5,17.5,26.5,6.0,27.4,4.5,4.0,0.8$, and $0.1 \mathrm{t}$, respectively (Kasamatsu 1993).

Results and discussion. Fig. 3 shows species diversity $\left(H^{\prime}\right)$, whale/dolphin density, and whale community biomass in relation to the distance from the ice-edge. Species diversity was lowest near the ice-edge. Species diversity became high and was constant in waters beyond $60 \mathrm{n}$ miles away from the ice-edge. Density and biomass showed the opposite trend: their values were highest near the ice-edge and decreased with distance from the ice-edge. This demonstrates that fewer species with large numbers and biomass dominated in the high-productivity region near the iceedge. Significant negative correlation was found in the relationship between the biomass and the species diversity $\left(\mathrm{R}^{2}=0.87, \mathrm{p}=0.021\right)$.

Fig. 4 shows the biomass composition in the whale community. Minke whales (baleen whales) represented $70 \%$ of the biomass near the ice-edge; the biomass of this species decreased with distance from the ice-edge. In contrast, the ratio of ziphiid (toothed
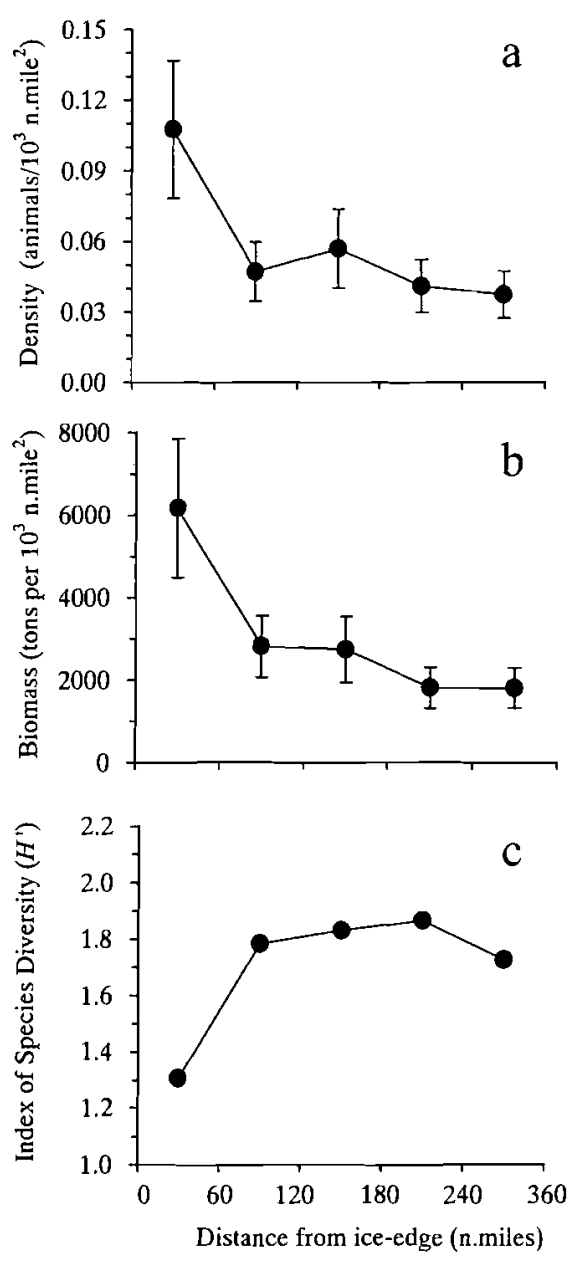

Fig. 3. (a) Biomass of cetacean community, (b) density of whales and dolphins, and (c) index of species diversity $\left(H^{\prime}\right)$ from the ice-edge which were observed by the vessels in each year. Vertical lines show the standard errors. $H^{\prime}$ calculated as $H^{\prime}=-\Sigma\left(N_{i j} / P_{j}\right) \log \left(N_{i j} / P_{j}\right)$, where $N_{i j}$ is the abundance of species $i$ in stratum $j$ and $P_{j}$ is the total abundance in stratum $j$ 


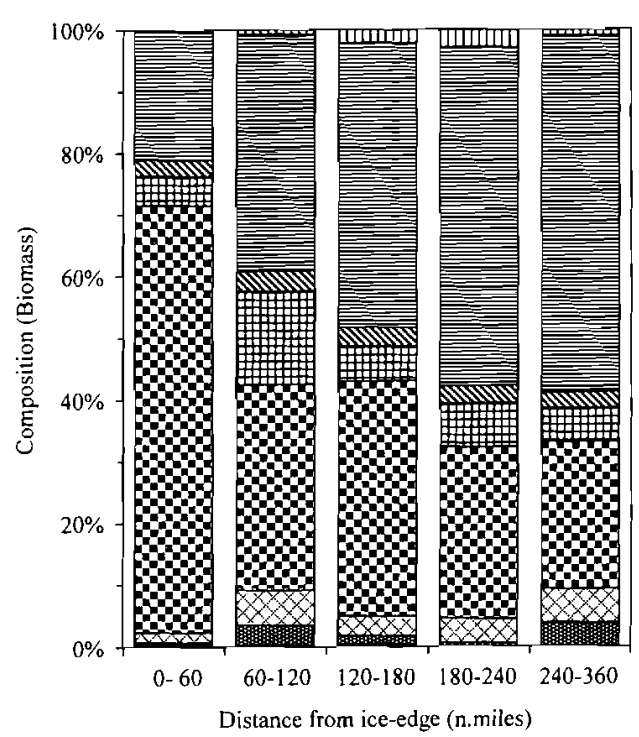

\begin{tabular}{|c|c|}
\hline Blue whale & 閆 Fin whale \\
\hline Sei whale & ⿴ Humpback whale \\
\hline Minke whale & Sperm whale \\
\hline $\mathbb{N}$ Killer whale & 旦 Ziphiids \\
\hline 미 Long-finned pilot whale & $\square$ Dolphins \\
\hline
\end{tabular}

Fig. 4. Biomass composition of whale community versus distance from the ice-edge

whales) biomass to the total biomass increased with distance from the ice-edge.

Because prey items are very different for baleen whales and toothed whales, the biomass of baleen whales (who feed exclusively on krill) and toothed whales (who feed primarily on oceanic squid) is shown separately (Fig. 5). The biomass of baleen whales near the ice-edge was larger than that of toothed whales but, with distance from the ice-edge, became smaller than that of toothed whales. The marginal ice zone (the region in which the transition from completely icecovered waters to water uninfluenced by the effects of pack ice occurs) is recognized as a major area of biological activity and productivity (mainly krill; see Ainley et al. 1986, 1988, Smith \& Nelson 1986, Eicken 1992). The high baleen whale biomass near the iceedge and the gradient from the ice-edge might be a reflection of that krill productivity. Although very little information is available on the distribution and abundance of the prey of toothed whales (mostly deep-sea squid, e.g. Gonatus antarcticus and Galiteushis glacialis), this study appears to demonstrate that prey availability for toothed whales is either constant in distribution or not correlated to the ice-edge. Habitat utilization patterns might have evolved to take advantage of the available food resources and to reduce competition for food among Antarctic whales (Kasamatsu \& Joyce 1995, Kasamatsu et al. 1996).

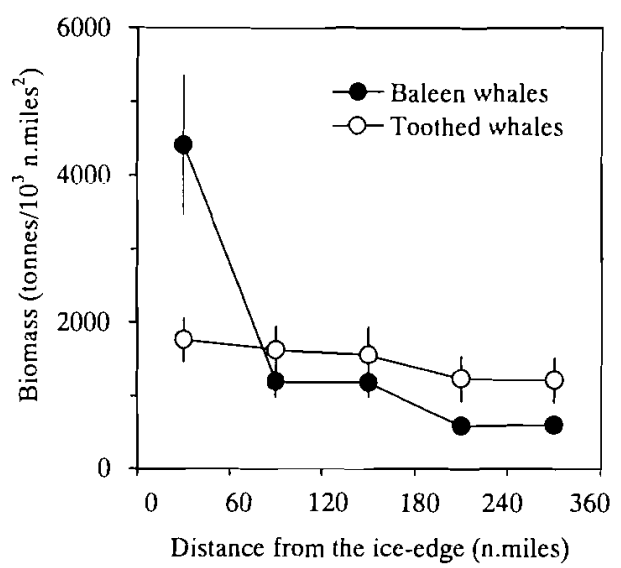

Fig. 5. Biomass of baleen whales and toothed whales (whales and dolphins)

Species diversity calculated to include sightings in this region indicates a possible increase over the temporal period of the present study $\left(H^{\prime}\right.$ value: 1.26 in $1978 / 79,1.46$ in $1984 / 85$, and 1.65 in $1988 / 89, r=0.99$, $p=0.056$ ). After the substantial removal of larger whales, the current minke whale population is thought to be twice that which existed before whaling, possibly a response to the great reduction in blue whale numbers (Laws 1985). Laws (1985) further pointed out that the increase in king penguins might have been caused by an increase in krill-feeding squids, which became more abundant because of the decrease in the number of sperm whales. It seems clear that the relative abundances of krill consumers have changed, and consequently the species diversity in the Southern Ocean may be quite different today than it was prior to whale exploitation. Possibly, the present spatial structure was established due to the influence of the numerical reduction of larger whales (such as blue, humpback, and sperm whales). Currently, the Antarctic whale community near the iceedge is dominated by minke whales. Recent evidence indicates a rapid recovery of at least one of the depleted large whale species (humpback whale) in the region between $70^{\circ}$ and $100^{\circ} \mathrm{E}$, south of $60^{\circ} \mathrm{S}$ (Bannister 1994, Nishiwaki et al. 1998). I suggest that the whale community is moving toward a new species balance (higher species diversity) in its recovery from past whaling

Acknowledgements. I thank the many people who contributed to the success of the sighting cruises between 1978 and 1989; Dr R. Gambell, Secretary of the International Whaling Commission, for providing access to the sighting data; and 3 anonymous reviewers for useful comments and improvements. Paul Ensor and Gerald G. Joyce kindly edited the English. 


\section{LITERATURE CITED}

Ainley DG, Fraser WR, Sullivan CW, Torres IJ, Hopkins TL, Smith WO (1986) Antarctic mesopelagic micronecton: evidence from seabirds that pack ice affects community structure. Science 232:847-849

Ainley DG, Fraser WR, Daly KL (1988) Effects of pack ice on the composition of micronektonic communities in the Weddell Sea. ln: Sahrhage D (ed) Antarctic ocean and resources variability. Springer-Verlag, Berlin, p 140-146

Bannister JL (1994) Continued increase in humback whales off Western Australia. Rep Int Whaling Comm 44:309-310

Bengston JL, Laws RM (1985) Trends in crabeater seal age at maturity: an Insight into Antarctic marine interactions. In: Siegfried WR, Condy PR, Laws RM (eds) Antarctic nutrient cycles and food webs. Springer-Verlag, Berlin, p 669-675

Best PB, Butterworth DS (1980) Report of the southern hemisphere minke whale assessment cruise, 1978/79. Rep Int Whaling Comm 30:257-283

Best PB, Ohsumi S (1980) International Whaling Commission/ International Decade of Cetacean Research (IWC/IDCR) Southern Minke Whale Assessment Cruise 1978/79. Polar Rec 20:52-57

Brown SG, Lockyer CH (1984) Whales. In: Laws RM (ed) Antarctic ecology, Vol 2. Academic Press, London, p 717-781

Buckland ST, Anderson DR, Burnham KP, Laake JL (1993) Distance sampling: estimating abundance of biological populations. Chapman and Hall, New York

de la Mare WK (1997) Abrupt mid-twentieth-century decline in Antarctic sea ice extent from whaling records. Nature 389:57-60

Eicken $H$ (1992) The role of sea ice in structuring Antarctic ecosystems. Polar Biol 12:3-13

Hunt GL Jr, Nettleship DN (1988) Seabirds of high-latitude northern and southern environments. Acta 19th Congr lnt Ornithol 1:1143-1155

Kasamatsu F (1993) Studies on distribution, migration, and abundance of cetacean populations occurring in the Antarctic waters. PhD thesis, University of Tokyo (in Japanese)

Kasamatsu F, Joyce GG (1995) Current status of odontocetes in the Antarctic waters. Antarct Sci 7:365-379

Kasamatsu F, Hembree D, Joyce G, Tsunoda L, Rowlett R, Nakano $T$ (1988) Distribution of cetacean sightings in the Antarctic: results from the IWC/IDCR southern hemisphere minke whale assessment cruises, 1978/791983/84. Rep Int Whaling Comm 38:449-487

Editorial responsibility: Otto Kinne (Editor),

Oldendorf/Luhe, Germany
Kasamatsu F, Joyce G, Ensor P, Mermoz J (1996) Current occurrence of Baleen whales in Antarctic waters. Rep Int Whaling Comm 46:293-304

Kasamatsu F, Ensor P, Joyce GG (1998a) Clustering and aggregations of minke whales in the Antarctic feeding grounds. Mar Ecol Prog Ser 168:1-11

Kasamatsu F, Joyce G, Ensor P, Kimura N (1998b) Distribution of minke whales in the Weddell Sea in relation to the sea-ice and sea surface temperature. Bull Jpn Soc Fish Oceanogr 62:334-342

Kasamatsu F, Ensor P, Joyce G, Kimura N (2000a) Distribution of minke whales in the Bellingshausen and Amundsen Seas $\left(60^{\circ} \mathrm{W}-120^{\circ} \mathrm{W}\right)$, with special reference to environmental/physiographic variables. Fish Oceanogr (in press).

Kasamatsu F, Matsuoka K, Hakamada T (2000b) Interspecific relationships in density among the whale community in the Antarctic. Polar Biol 23:466-473

King JE (1964) Seals of the world. British Museum (Natural History), London

Laws RM (1977) Seals and whales of southern ocean. Philos Trans R Soc Lond Ser B Biol Sci 279:81-96

Laws RM (1985) The ecology of the Southern Ocean. Am Sci 73:26-40

Loeb V, Seigel V, Holm-Hansen O, Hewitt R, Fraser W, Triveloiece W, Triveloice S (1997) Effects of sea ice extent and krill or salpa dominance on the Antarctic food web. Nature 387:897-900

Mackintosh NA (1965) The stocks of whales. Fishing News, London

Nishiwaki S, Matsuoka K, Hakamada T, Kasamatsu F (1998) Yearly changes in the distribution and abundance of humpback whales in the Antarctic $\left(70^{\circ} \mathrm{E}-170^{\circ} \mathrm{W}\right)$. In: New Zealand Natural Sciences, Vol 23, Supplement, Late and Altered Abstracts, VII SCAR Biology Symposium, 31 August-4 September, 1998, University of Canterbury, Christchurch

Pielou EC (1966) Species-diversity and pattern-diversity in the study of ecological succession. J Theor Biol 10: 370-383

Shannon CE, Weaver W (1963) The mathematical theory of communication. Univ Illinois Press, Urbana

Siegel V, Loeb V (1995) Recruitment of Antarctic krill Euphausia superba and possible causes for its variability. Mar Ecol Prog Ser 123:45-56

Smith WO, Nelson DM (1986) Importance of ice edge phytoplankton production in the Southern Ocean. BioScience 36:251-257

Tonnessen JN, Johnsen AO (1982) The history of modern whaling. C Hurst \& Co Publishers Ltd, London

Submitted: June 3, 1999; Accepted: April 20, 2000

Proofs received from author(s): June 5, 2000 